"Relationship between financial innovation, financial depth, and economic growth"

\begin{tabular}{|c|c|c|}
\hline AUTHORS & \multicolumn{2}{|l|}{$\begin{array}{l}\text { Yuliia Shapoval (iD } \\
\text { R }\end{array}$} \\
\hline ARTICLE INFO & \multicolumn{2}{|c|}{$\begin{array}{l}\text { Yuliia Shapoval (2021). Relationship between financial innovation, financial } \\
\text { depth, and economic growth. Investment Management and Financial Innovations, } \\
\text { 18(4), 203-212. doi:10.21511/imfi.18(4).2021.18 }\end{array}$} \\
\hline DOI & \multicolumn{2}{|c|}{ http://dx.doi.org/10.21511/imfi.18(4).2021.18 } \\
\hline RELEASED ON & \multicolumn{2}{|l|}{ Monday, 22 November 2021} \\
\hline RECEIVED ON & \multicolumn{2}{|l|}{ Friday, 17 September 2021} \\
\hline ACCEPTED ON & \multicolumn{2}{|l|}{ Friday, 12 November 2021} \\
\hline LICENSE & \multicolumn{2}{|c|}{$\begin{array}{l}\text { This work is licensed under a Creative Commons Attribution } 4.0 \text { International } \\
\text { License }\end{array}$} \\
\hline JOURNAL & \multicolumn{2}{|c|}{ "Investment Management and Financial Innovations" } \\
\hline ISSN PRINT & \multicolumn{2}{|l|}{$1810-4967$} \\
\hline ISSN ONLINE & \multicolumn{2}{|l|}{$1812-9358$} \\
\hline PUBLISHER & \multicolumn{2}{|c|}{ LLC "Consulting Publishing Company "Business Perspectives" } \\
\hline FOUNDER & \multicolumn{2}{|c|}{ LLC "Consulting Publishing Company "Business Perspectives" } \\
\hline$\sigma^{\infty}$ & 15 & 三泣 \\
\hline NUMBER OF REFERENCES & NUMBER OF FIGURES & NUMBER OF TABLES \\
\hline 34 & 0 & 3 \\
\hline
\end{tabular}

(c) The author(s) 2021. This publication is an open access article. 


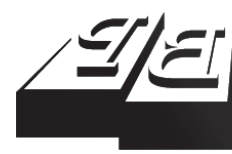

BUSINESS PERSPECTIVES

(O)

LLC "CPC "Business Perspectives"

Hryhorii Skovoroda lane, 10

Sumy, 40022, Ukraine

www.businessperspectives.org

Received on: $17^{\text {th }}$ of September, 2021 Accepted on: $12^{\text {th }}$ of November, 2021 Published on: $22^{\text {nd }}$ of November, 2021

(c) Yuliia Shapoval, 2021

Yuliia Shapoval, Ph.D. in Economics, Scientific Fellow, Department of Monetary Relations, Institute for Economics and Forecasting, National Academy of Sciences of Ukraine, Ukraine.

Yuliia Shapoval (Ukraine)

\title{
RELATIONSHIP BETWEEN FINANCIAL INNOVATION, FINANCIAL DEPTH, AND ECONOMIC GROWTH
}

\begin{abstract}
The intrinsic property of modern economic development is financial deepening in the light of incremental spearheading financial innovation opportunities. The paper deals with the relationship between financial depth, financial innovation, and economic growth among 22 OECD economies over $2007-2018$ by applying pooled OLS and fixed effect panel data regression analysis. The purpose of the paper is to empirically test whether the economic growth depends on financial depth, financial innovation, and institutional environment (Worldwide Governance Indicators). The findings shed light on the recent discussion on the pros and cons of financial innovation. The estimation results show that while financial depth is a strong predictor of economic growth across high- and upper-middle-income economies, financial innovation is a slightly weaker predictor. Despite the identified positive impact of financial innovation on economic growth, it is asserted that the negative effect of financial depth may indicate oversaturated financial market in developed countries. Consistent with the general notion that the institutional framework promotes the capacity of the financial sector for financial innovations implementation, this paper states that financial depth and financial innovations are better prerequisites of economic growth than institutional development.
\end{abstract}

\section{Keywords}

JEL Classification

\section{INTRODUCTION}

Financial deepening plays a vital role in economic growth, since it helps to mobilize liquidity in financial markets and direct it into financing for innovation, leading to economic growth. At the same time, financial depth depends on implementing financial innovations that stimulate the transformation of relationships between central banks, depository corporations, and population. Widespread economic-related uncertainty has brought up the role of financial innovation in minimizing the effects of the economic instability after the COVID-19 pandemic.

In general, over the last decade, a trend towards rapid development of financial innovations (blockchain and related applications, mobile money, etc.) has led to the appearance of new types of financial instruments and intermediaries, explicitly changing payments, savings, borrowing, and investments. If earlier the positive impact of financial innovations on economic development has been predominantly seen in developing countries, today more and more developed countries are implementing risky and simultaneously expensive financial innovations. Lower funding levels with research and development and lower incentives for innovation investments by private entities characterize developing countries. 
Digital transformation of economic processes causes changes in the business models of interaction with customers (wide use of remote services) and in the application of artificial intelligence in complex scoring systems that assess the borrower's solvency, shift from fixed assets to digital (causing the rise of public and private digital currencies) and from physical equipment to cloud computing. Under changing legislative rules and, consequently, due to pressures from financial regulators, regulated entities favor automating reporting processes with the aid of Regtech and Suptech. Although the development of financial innovations can surge the financial inclusion of population by improving financial market infrastructure, and on this basis contributing to economic growth, uncontrolled innovation can also lead to financial shocks. For instance, ease of obtaining a loan due to innovative solutions under low financial literacy creates risks for both borrowers and providers of such funding. Thus, effective use of a financial innovation requires in-depth knowledge of its consequences for economic development.

\section{LITERATURE REVIEW}

The academic community empirically and theoretically depicts the consequences of the nature of innovations for economic development. According to Schumpeter (2017, p. 19), innovation is the commercial or industrial application of something new: a new product, process, or method of production; a new market or source of supply; a new form of commercial, business, or financial organization. Financial innovation drives the financial system toward facilitating the allocation and deployment of economic resources, both spatially and across time, in an uncertain environment (Merton, 1992, p. 12). Further, Merton (1995, p. 36) describes financial innovations as the engine driving the financial system toward its goal of greater economic efficiency, stating that they improve efficiency by completing markets, lowering transaction costs, and reducing agency costs. Likewise, Tufano (2003) notes that financial innovation is an ongoing process whereby private parties experiment to differentiate their products and services, responding to both sudden and gradual changes in the economy (p. 309).

The innovation-growth view states that improvements in the financial sector encourage more saving and investment, and more productive investment decisions (Frame \& White, 2004, p. 4). Financial innovation positively influences economic growth because the increasing sophistication and depth of financial markets lead to the allocating the capital where it can be most productive (Bernanke, 2007). It provides possibilities to finance innovative technological projects in case of unavailable traditional funds sources because of high investment risk (Błach, 2011). Michalopoulos et al. (2009) demonstrate that financiers innovate by inventing better methods for screening entrepreneurs (which becomes obsolete as technology advances), generating monopoly rents and hence the economic motivation for financial innovation (p. 29). Besides efficient financial intermediation, financial innovation also promotes financial inclusion by expanding access and usage of financial services by the unbanked population due to the development of banking and non-banking facilities (Shapoval et al., 2021).

At the same time, Johnson and Kwak (2012) highlight the necessity to consider whether financial innovation leads to beneficial financial intermediation or causes excessive and destructive financial intermediation. For instance, Michalopoulos et al. (2009) specify that the securitization of assets can neglect the positive impact of financial innovation, since financial innovation, while facilitating the transfer of credit risk by financial institutions, can hinder the verification and monitoring, damaging financial stability (p. 29). Hsu et al. (2014) indicate that industries that are more dependent on external financing and are more technology innovative demonstrate a disproportionately higher level of innovation in countries with developed stock markets. However, the development of credit markets hinders this effect. In turn, Beck et al. (2016, p. 1) drew attention to credit expansion, risky securities, and assisting banks in designing structured products to exploit investors' misunderstandings of financial markets. It is concluded that financial innovations, associated with more aggressive risk-taking by banks and higher bank growth (which helps to provide valuable credit and risk diversification services to firms and households), simultaneously increase the banks' profit volatility, 
their fragility, and losses (p. 28). Asimakopoulos and Zhu (2018) stress that too many finances negatively affect the quantity and quality of innovation activities among 50 countries over the 19902016 period. The positive impact of innovation on growth is minor or even insignificant for countries with a developed financial sector.

Besides financial crises, according to Jia et al. (2021), economic uncertainty is presented as an adverse factor in the prospects of innovativeness that deteriorates financial development. Moreover, regulations that limit financial innovation can negatively affect economic growth. Thus, the efficiency gained from financial innovations cannot be obtained without simultaneous changes in the institutional environment. On the other hand, Tufano (2003) summarizes innovation-stimulating factors: inherently incomplete markets; inherent agency concerns and information asymmetries; transaction, search, or marketing costs; taxes and regulation; increasing globalization and perceptions of risk; and technological shocks.

Sahay et al. (2015) affirm that institutional and regulatory frameworks limit financial deepening as better protection of property rights, creditor rights, information, higher regulatory quality and the rule of law are positively associated with greater financial development (p. 28). Williams (2019) summarizes that democratic institutions lessen the negative effect of extensive credit market deepening on economic growth in emerging and developing economies. Khan et al. (2020) express that the financial regulatory framework in developing and emerging countries depends on governance and quality institutions. In their turn, Olaniyi and Oladeji (2020) point out that in 19862015, both financial deepening and institutional development negatively affect economic growth in the short term, while two macroeconomic factors have substantial individual positive impacts on Kenya's economic growth in the long term.

With the rise of FinTech, Ukrainian researchers primarily focus on financial innovations in creating and supplying banking and non-banking services, in particular the design of novel securities and blockchain. Rzayev and Samoilikova (2020), referring to the cases of Azerbaijan and Ukraine, substantiate that business (unlike the state) is the best consumer of R\&D due to more excellent financial opportunities to implement them faster in production, which contributes to economic growth.

The assessment of financial innovations' role is predominantly qualitative, as one of the significant concerns is the lack of data that can give a distorted view of financial innovation. Most studies use R\&D expenditure and patenting data in reflection of their contribution to economic growth. In contrast, Qamruzzaman and Jianguo (2017) and Nazir et al. (2021) also use the ratio of broad money to narrow money (M2/M1) to measure financial innovation in Bangladesh, China, India, and Pakistan.

Alternatively, Kapidani and Luci (2019), having observed 15 developing countries for 1996-2016, state that the number of patents indicates the country's innovation activity. A higher level of banking sector lending positively affects the number of patents. Provision of lending by stock markets or non-banking institutions shows lower efficiency of innovation and the opposite effect on the number of patents. Das (2020) notes that in high- and middle-income countries during 19962017, R\&D expenditures, number of patents, and per capita income growth have no long-run equilibrium relationship, but in the short-run income growth and number of patents make a cause to R\&D spending. Gumus and Celikay (2015) claim that although during 1996-2010 in the analyzed 52 countries $R \& D$ expenditures have a strong and positive effect on GDP in both the short and long run for the developed countries, for the developing countries the effects are strong in the long-run and weak in the short-run (p. 215). Concerning the long-run effects of innovations, Freimane and Balina (2016) conclude that there is a need for more research financing for sustainable economic growth as the statistically significant impact of $\mathrm{R} \& \mathrm{D}$ expenditure stocks on growth in real GDP per person employed in the EU countries. At the same time, for low R\&D expenditures (less than 1 $\%$ per GDP), R\&D activities are even more important and necessary for GDP growth (Freimane \& Balina, 2016, p. 10). In turn, Pradhan et al. (2018) justify that both innovation and financial development are key drivers of per capita economic growth in the long run, namely over 1961-2014 
in $49 \mathrm{EU}$ countries (p. 10). Kiselakova et al. (2020) advocate a statistically significant impact of innovation (measured via high-tech exports, gross domestic expenditure on $\mathrm{R} \& \mathrm{D}$, government expenditure on education, direct investment, and tertiary educational attainment) on the economic growth of the 28 EU countries over 2010-2018. Specifically, Mtar and Belazreg (2021) find unidirectional causality over 2001-2016 from innovation to economic growth for Spain, Norway, the UK, Sweden, and Turkey; financial development to economic growth for Australia, Chile, Denmark, Finland, the Czech Republic, and Switzerland; economic growth to innovation for Chile, Denmark, Spain, the USA, Greece, Italy, Mexico, the Netherlands, the Czech Republic, and Sweden; financial development to innovation for Ireland, Iceland, Luxembourg, Sweden, Switzerland, and Turkey; economic growth to financial development for Denmark, the Czech Republic, Finland, Germany, Luxembourg, Portugal, Spain, Sweden, Turkey, and the UK; innovation to financial development for Belgium, Spain, Korea, Iceland, the Czech Republic, and Turkey. Jiang et al. (2021) call out that digital finance (coverage breadth, usage depth, and digitalization level) has a positive and significant impact on economic growth in China, to a large extent of underdeveloped regions with lower urbanization and lower physical capital levels.

Given financial depth effect on innovation, Trinugroho et al. (2021) suggest the positive impact of both credit and equity market development on innovation level up to a particular stage of financial development in 69 developed and emerging economies during 1995-2018. Specifically, developed financial markets that enriched credit and firm financial information would encourage market monopolization behavior through the credit market bias in financing or existing large firms absorbing new innovative firms (p. 14). Levine (2021) supports the idea that the financial development deteriorates in screening, governing, managing risks, mobilizing savings, and easing transactions without financial innovation implementation.

Thus, despite the intense interest in financial innovations and associated positive and negative effects, while assessing their impact on economic growth, it is concluded that more patents and financial resources allocated to $R \& D$ activities re- sult in higher economic development. Meanwhile, the institutional environment for financial innovations is vital to foster financial development and adopt innovations in the economy. The regulatory framework enables innovative financing since financial sector reforms lead to risk diversification, higher capital accumulation and investment opportunities, and efficient financial intermediation.

Based on all previous theoretical backgrounds, this study aims to examine the relationship between financial depth, financial innovation, and economic growth using the latest data and panel data analysis. Following the study aim, the next two hypotheses were formulated:

H1: Economic growth is not related to financial depth, financial innovation, and institutional development.

H2: Dependence between economic growth, financial depth, financial innovation, and institutional development is not robust.

The study adopts that $H 1$ is rejected if estimation results show that corresponding variables are not significant at a $10 \%$ significance level. $H 2$ is rejected if estimation results show that corresponding variables retain their significance when tested using different regression specifications.

\section{METHODS}

For the regression analysis panel data was employed with the use of the following methods: pooled OLS and fixed effect (FE). Calculations are performed via "gretl" software package.

The relationship tested in this study can be summarized using such equation:

$$
Y_{t}=f(F D ; F I ; I D)
$$

where $Y_{t}$ is economic growth, $F D$ is financial depth, $F I$ is financial innovation and $I D$ is institutional development.

Worldwide Governance Indicators governing indicators are included in the regression analysis due to the prevalence of the financial market model in 
developed countries, at which financial depth is achieved due to their financial resource potential and institutional environment.

The dependent variable is economic growth and is represented by GDP in PPP US dollars at current prices.

The independent variables are:

- financial depth, which is represented by domestic credit to the private sector in relation to GDP;

- financial innovation, which is represented by R\&D expenditures by financial and insurance activities in PPP US dollars at current prices;

- institutional development, which is represented by a set of six Worldwide Governance Indicators (WGIs): voice and accountability, political stability, absence of violence/terrorism, government effectiveness, regulatory quality, the rule of law, and control of corruption. All of these variables are in percentile points, varying within a -2.5 to 2.5 interval.

The paper is based on the annual data provided by the World Bank (n.d.) and OECD's (2021) ANBERD database. The sample covers high- and upper-middle-income economies. The choice of countries is limited to recent R\&D expenditure statistics on financial activity, which is available only for high-income OECD countries. Hence, the study covers Australia, Austria, Belgium, the Czech Republic, Estonia, Finland, France, Germany, Italy, Japan, Korea, Lithuania, Mexico, the Netherlands, Norway, Poland, Portugal, Slovenia, Sweden, Spain, Turkey, and the United States, spanning 2007-2018.

\section{RESULTS}

Based on an unbalanced panel of data from 22 countries during 2007-2018, the study empirically tests whether the economic development depends on financial depth, financial innovation, and to some or all of the Worldwide Governance Indicators, which represent institutional development of respective countries. The unbalanced panel is used due to not being available in the data source used, specifically on financial and insurance activities and financial depth. Therefore, observations are missing. If an unbalanced panel contains $\mathrm{N}$ panel members and T periods, then the following strict inequality holds for the number of observations (n) in the dataset: $n<N \times T$. The descriptive statistics of available data can be seen in Tables 1 and 2 .

To do that, several pooled OLS and fixed effect panel data regressions are run with different sets of variables to determine which variables retain their significance, and therefore can be considered to be affecting economic growth. The results are presented in Table 3.

Model 1 is a pooled OLS model that includes all of the available variables. Regulatory quality and the rule of law are the only variables that are in-

Table 1. Summary statistics: macroindicators

\begin{tabular}{|c|c|c|c|c|c|c|}
\hline Variable & Mean & Std. deviation & Min & Max & No. of countries & No. of observations \\
\hline $\begin{array}{l}\text { Financial and insurance } \\
\text { activities, PPP USD }\end{array}$ & $4.0022 e+008$ & $1.0411 e+0.009$ & 0 & $7.6160 e+009$ & 22 & 255 \\
\hline Financial depth, \% & 97.85 & 42.78 & 20.67 & 206.67 & 22 & 260 \\
\hline GDP, PPP USD & $1.9321 \mathrm{e}+012$ & $3.5064 e+012$ & $2.7503 e+010$ & $2.0612 \mathrm{e}+013$ & 22 & 264 \\
\hline
\end{tabular}

Table 2. Summary statistics: world governing indices

\begin{tabular}{|c|c|c|c|c|c|c|}
\hline Variable & Mean & Std. deviation & Minimum & Maximum & No. of countries & No. of observations \\
\hline Voice and accountability & 0.9489 & 0.8735 & -2.2705 & 1.7380 & 22 & 264 \\
\hline Political stability & 0.6361 & 0.6226 & -2.0091 & 1.4878 & 22 & 264 \\
\hline Government efficiency & 1.2524 & 0.5298 & -0.1576 & 2.2410 & 22 & 264 \\
\hline Regulatory quality & 1.1978 & 0.4730 & 0.0151 & 2.0507 & 22 & 264 \\
\hline Rule of law & 1.2154 & 0.6543 & -0.6679 & 2.1297 & 22 & 264 \\
\hline Control of corruption & 1.1446 & 0.7720 & -0.8549 & 2.4005 & 22 & 264 \\
\hline
\end{tabular}


Table 3. Test models variables' coefficients

\begin{tabular}{|c|c|c|c|c|c|}
\hline & Pooled OLS & Pooled OLS & FE Panel & FE Panel & FE Panel \\
\hline Variable name & $\begin{array}{c}\text { Model } 1 \\
\left(A \_R^{\wedge} 2=0.7480\right)\end{array}$ & $\begin{array}{c}\text { Model } 2 \\
\left(A \_R^{\wedge} 2=0.7481\right) \\
\end{array}$ & $\begin{array}{c}\text { Model } 3 \\
\left(W_{R} R^{\wedge} 2=0.8302\right)\end{array}$ & $\begin{array}{c}\text { Model } 4 \\
\left(W_{-} R^{\wedge} 2=0.4298\right)\end{array}$ & $\begin{array}{c}\text { Model } 5 \\
\left(W_{-} R^{\wedge} 2=0.9445\right) \\
\end{array}$ \\
\hline $\begin{array}{l}\text { Financial and insurance } \\
\text { activities, PPP USD }\end{array}$ & $2308.29 * * *$ & $2268.75^{* * *}$ & $831.196 * * *$ & & \\
\hline $\begin{array}{l}\text { Log (Financial and insurance } \\
\text { activities) }\end{array}$ & - & - & - & $0.045^{* * *}$ & 0.004 \\
\hline Financial depth, \% & $2.61 e+010 * * *$ & $2.67 e+010 * * *$ & $-2.87 e-09 *$ & $-0.004 * * *$ & $-0.001^{* * *}$ \\
\hline Voice and accountability & $6.18 \mathrm{e}+011^{* * *}$ & $6.31 \mathrm{e}+011^{* * *}$ & $-1.21 \mathrm{e}-012^{* * *}$ & $-0.831 * * *$ & -0.002 \\
\hline Political stability & $-1.24 \mathrm{e}-012^{* * *}$ & $-1.29 e-0.12 * * *$ & $-3.03 e-011^{* * *}$ & $-0.24 * * *$ & -0.008 \\
\hline Government efficiency & $3.97 e+012 * * *$ & $3.85 e+0.12 * * *$ & $3.34 \mathrm{e}+011^{* *}$ & - & - \\
\hline Regulatory quality & $-739 e-011$ & - & $4.46 \mathrm{e}+011^{* * *}$ & $0.302 * * *$ & 0.024 \\
\hline Rule of law & $1.86 e+010$ & - & $1.57 e+011$ & $0.385^{* * *}$ & -0.019 \\
\hline Control of corruption & $-2.95 e-012 * * *$ & $-3.25 e-012 * * *$ & $-2.02 \mathrm{e}-011$ & - & - \\
\hline Lagged $\log ($ GDP) & - & - & - & - & $0.979 * * *$ \\
\hline
\end{tabular}

Note: $* * *$ means that the coefficient is significant at $1 \%$ significance level; $* *$ means that the coefficient is significant at $5 \%$ significance level; * means that the coefficient is significant at $10 \%$ significance level; - means that variable is below zero.

significant in this composition. Political stability and control of corruption are significant yet have a negative impact on economic growth. The rest of the variables, namely, government efficiency, voice and accountability, financial depth, and financial and insurance activities, have a significant positive relation to GDP. The magnitude of coefficients mainly shows the magnitude difference between the dependent variable, denoted in PPP, US dollars, and the majority of other factors, denoted in single and double-digit percentile points, thus predominantly, the direction and significance are to be taken into account.

The paper excludes the insignificant variables that resulted in Model 2, which had a negligible increase in its R-squared as a result. The tests carried out on this model show that it does not appear to break any of the major regression assumptions. It has no autocorrelation of the first order. It is a correctly specified model depicting a linear dependence; heteroskedasticity is not present, and the residuals are distributed normally. However, the correlation matrix between the variables implies a possibility of multicollinearity, and the Pesaran test shows cross-sectional dependence. In practice, this may mean unreliable coefficients and standard errors and possible underperformance of standard panel data models on the present dataset. Multicollinearity can be alleviated by excluding some of the indicators from pairs that have the highest mutual correlation. The correlation matrix indicates that the WGIs have the strongest mutual correlation, and thus some of them must be excluded.
Although Model 3 also includes the full set of study variables, it uses a fixed effect panel model on the assumption that the relations it tries to capture are fixed and not random. However, the model returns a near-singularity matrix error, which implies incorrect specification. It can be alleviated by replacing the biggest scope variables (GDP and financial and insurance activities, denominated in PPP, US dollars) with their respective logarithms and excluding the non-significant variables. The resulting Model 4 has no insignificant variables and an $\mathrm{R}$-squared of 0.43 . This means a moderate to a weak connection between the variables included and the dependent variable and indicates that the model omits some significant predictors. The logarithm of financial and insurance activities still has a significant positive effect on economic growth, however financial depth is now shown to have a negative impact. Regulatory quality and the rule of law have a significant positive impact on economic growth, while voice, accountability, and political stability have significant negative impacts. Further, considering relatively low R-squared, the connection between variables by including a strong predictor, the dependent variable, lagged by one period, is tested. The resulting Model 5 shows that only financial depth retains its significance under such specifications, as well as its negative effect.

To summarize, among the tested variables, financial and insurance activities have a significant and positive effect on economic growth in both pooled OSL and fixed effect panel data models. However, it disappears if a lagged economic growth is in- 
cluded in the equation, which means the latter has most of the explanatory power of the former. Financial depth retains a significant effect on economic growth regardless of the model used, which means it is the most powerful predictor for economic growth across variables tested. It switches its effect from positive in pooled OLS models to negative in FE models. The effects of WGIs are inconsistent: all of them lose significance in the presence of a strong predictor. Aside from that, voice and accountability have a significant positive impact in pooled OLS models and a significant negative impact in FE models. Political stability has a significant negative impact on all models. Government efficiency has a significant positive effect in all models. Regulatory quality is insignificant in pooled OLS models but has a significant positive impact in FE ones. The rule of law is only significant in Model 4, and its effect is positive. Control of corruption has a stable negative impact on economic growth, but it is only significant in pooled OLS models.

\section{DISCUSSION}

Based on the study conducted, it is concluded that financial depth is a significant factor in economic growth, regardless of the approach used, which is in line with the current consensus on the financial development - economic growth nexus. Financial depth is found to positively affect economic growth if assessed using pooled OLS models and negative - if FE panel models are used instead. However, the existence of cross-sectional dependence within the latest data set indicates that FE panel models might be inferior to pooled OLS ones - a conclusion that is further enforced by the number of significant variables and the difference in magnitude of R-squared among the models. Another explanation for financial depth switching the direction of its impact on economic growth is that FE models capture the fixed, i.e. constant effects of variables they case every year, while pooled OLS models capture the effect accumulated during the entire study period. Hence, while the accumulated effect might be positive due to the older observations, the "too much finance" effect, described by Sahay et al. (2015), becomes visible as soon as the fixed effects are taken into account instead.
Financial innovation is also found to be significant across the board - it only loses its explanatory power with the inclusion of a lagged economic growth variable, which of course, accounts, among other things, for the historical impact of financial innovation. It is also worth noting that the effect of financial innovation on economic growth is universally positive, which supports a fairly obvious conclusion that a high level of financial innovation is a predictor of economic growth.

The WGIs are included mainly as control variables to determine how changes in institutional development affect economic growth and which aspects of institutional development are relevant to highly developed countries at this stage. Voice and accountability is an arbitrary measure of freedom of speech and accountability of state officials, and therefore have little to do with financial matters, except for the state finance, which generally does not participate in financial innovation or contribute to financial depth. Therefore, it is not surprising that the main variables of the study do not overshadow the significance of this variable, and it is the third most influential variable; its dynamic is similar to the dynamic of financial depth; in FE models, it changes its influence from positive to negative, and only loses significance when used with the lagged variable. This may suggest a slight over-abundance of procedures used for accountability control that stifle economic activity, or it could just be a fluke since all WGIs are effectively expert-method-based questionnaires. Political stability is another of the WGIs, which shows the possibility of unrest or politically motivated violence. Since it is even less tied to the financial sector than the previous indicator, it stays significant across all of the models; its influence is negative in all instances, which can be another sign of over-regulation that slows down the economic activity and be specific to highly developed countries. Government efficiency shows the efficiency of government regulations, and it only retains its significance in the pooled OLS models. Its impact on economic growth is positive, and it is stronger relative to the other WGIs. This shows the adequacy of government regulations in the developed economies during the period of the study. The next WGI, regulatory quality, estimates the quality of legislation existent in the country. Since both the financial innovations and financial depth are 
dependent on regulatory quality, this indicator is one of the less significant ones. Its effect on economic growth is mostly positive, except for Model 1 , in which it is not significant. The rule of law is another WGI on which any contract-based activity is dependent, and thus its explanatory power is also mostly transferred to financial depth and financial innovation indices. It is only significant in Model 4, and its effect is primarily positive, indicating the satisfactory quality of the rule of law in the countries examined. Lastly, the control of corruption is only significant in pooled OLS models, and its impact is negative, likely indicating over-regulation in this area.

\section{CONCLUSION}

The purpose of this paper has been to analyze, using pooled OLS and FE panel models, if financial depth, proxied by domestic credit to the private sector, financial innovation, proxied by financial and insurance activities and R\&D expenditures, and institutional development, proxied by Worldwide Governance Indicators affecting economic growth, proxied by GDP, focusing on 22, primarily developed, countries over 2007-2018. The obtained results show that, in comparison to financial innovation, financial depth is a stronger predictor of economic growth. This is because high financial R\&D expenditures, favorable at first glance, are not always related to higher economic development because of their innovation efficiency due to allocation of resources in innovation activity.

Secondly, although this paper does not empirically support the vital role of financial innovation in economic growth, it highlights that financial depth and financial innovation have a mostly positive influence on economic growth. The evolution of financial innovation allows economies to grow faster by exploiting exogenously given growth opportunities in financing, productivity, and risk management. While financial innovation is an unambiguously positive factor of economic growth, a negative impact from financial depth may indicate a slight finance over-saturation of the developed economies and, consequently, approaching the threshold above which financial depth no longer has a positive effect on economic development.

Further, the WGIs have inconsistent significancies across different models. The less significant WGIs are the most connected to financial sector functionality. Therefore, their explanatory power is likely to be blotted out by financial depth and financial innovations as more powerful predictors. The more significant WGIs generally show high levels of institutional development in the countries studied, with a hint of over-regulation, which may be slowing down economic growth.

Economic growth of developed countries is being achieved through, first and foremost, the financial depth and financial innovations and, to a lesser extent, through institutional development. Even though the influence of this latter factor is relatively weak, it is not prudent to ignore it since a strong institutional development serves as a prerequisite for better reallocation of financial resources towards high-productivity branches of national economies. In other words, while financial depth serves as a resource base for financial innovation, which creates economic growth opportunities, the institutions provide the framework for such interaction.

\section{AUTHOR CONTRIBUTIONS}

Conceptualization: Yuliia Shapoval.

Data curation: Yuliia Shapoval.

Formal analysis: Yuliia Shapoval.

Funding acquisition: Yuliia Shapoval.

Investigation: Yuliia Shapoval.

Methodology: Yuliia Shapoval. 
Project administration: Yuliia Shapoval.

Resources: Yuliia Shapoval.

Software: Yuliia Shapoval.

Supervision: Yuliia Shapoval.

Validation: Yuliia Shapoval.

Visualization: Yuliia Shapoval.

Writing - original draft: Yuliia Shapoval.

Writing - review \& editing: Yuliia Shapoval.

\section{ACKNOWLEDGMENT}

The paper was funded as a part of the "Relationship between financial depth and economic growth in Ukraine" research project (No. 0121U110766), conducted in the State Institution "Institute for Economics and Forecasting of the NAS of Ukraine".

\section{REFERENCES}

1. Asimakopoulos, S., \& Zhu, X. (2018). Financial Development and Innovation-led Growth: Is Too Much Finance Better? SSRN Electronic Journal. http://dx.doi. org/10.2139/ssrn.3289127

2. Beck, T., Chen, T., Lin, C., \& Frank, M. S. (2016). Financial innovation: the bright and the dark sides. Journal of Banking \& Finance, 72, 28-51. https:// doi.org/10.1016/j.jbankfin.2016.06.012

3. Bernanke, B. (2007). Regulation and Financial Innovation. Federal Reserve Bank of Atlanta's 2007 Financial Markets Conference. Sea Island, Georgia. Retrieved from https://www.federalreserve. gov/newsevents/speech/bernanke20070515a.htm

4. Błach, J. (2011). Financial innovations and their role in the modern financial system-identification and systematization of the problem. e-Finanse: Financial Internet Quarterly, 7(3), 13-26. Retrieved from http://hdl.handle.net/10419/66758

5. Das, R. C. (2020). Interplays among R\&D spending, patent and income growth: new empirical evidence from the panel of countries and groups. Journal of Innovation and Entrepreneurship, 9(1), 1-22. https://doi.org/10.1186/ s13731-020-00130-8

6. Frame, W. S., \& White, L. J. (2004). Empirical studies of financial innovation: lots of talk, little action? Journal of economic literature, 42(1), 116-144. https://doi. org/10.1257/002205104773558065

7. Freimane, R., \& Bāliņa, S. (2016). Research and development expenditures and economic growth in the EU: A panel data analysis. Economics and Business, 29(1), 5-11. https://doi.org/10.1515/eb2016-0016

8. Gumus, E., \& Celikay, F. (2015). R\&D Expenditure and Economic Growth: New Empirical Evidence. The Journal of Applied Economic Research, 9(3), 205-217. https://doi. org/10.1177/0973801015579753

9. Hsu, P. H., Tian, X., \& Xu, Y. (2014). Financial development and innovation: Cross-country evidence. Journal of Financial Economics, 112(1), 116-135. https://doi.org/10.1016/j.jfineco.2013.12.002

10. Jia, Z., Mehta, A. M., Qamruzzaman, M., \& Ali, M. (2021). Economic Policy Uncertainty and Financial Innovation: Is There Any Affiliation? Frontiers in Psychology, 12. https://doi.org/10.3389/ fpsyg.2021.631834

11. Jiang, X., Wang, X., Ren, J., \& Xie, Z. (2021). The Nexus between Digital Finance and Economic Development: Evidence from China. Sustainability, 13(13), 7289. https://doi.org/10.3390/ su13137289
12. Johnson, S., \& Kwak, J. (2012). Is Financial Innovation Good for the Economy? Innovation Policy and the Economy, 12, 1-16. https://doi. org/10.1086/663153

13. Kapidani, M., \& Luci, E. (2019). The Effects on Innovation from Financial Sector Development: Evidence from Developing Countries. Journal of Competitiveness, 11(2), 84-94. https://doi.org/10.7441/ joc.2019.02.06

14. Khan, H., Khan, S., \& Zuojun, F. (2020). Institutional Quality and Financial Development: Evidence from Developing and Emerging Economies. Global Business Review. https://doi. org/10.1177/0972150919892366

15. Kiselakova, D., Sofrankova, B., Onuferova, E., \& Cabinova, V. (2020). Assessing the effect of innovation determinants on macroeconomic development within the EU (28) countries. Problems and Perspectives in Management, 18(2), 277-289. https://doi.org/10.21511/ ppm.18(2).2020.23

16. Levine, R. (2021). Finance, Growth, and Inequality (IMF Working Papers No. 2021(164), A001). International Monetary Fund. Retrieved from https:// www.elibrary.imf.org/view/journals/001/2021/164/article-A001en.xml

17. Merton, R. C. (1992). Financial innovation and economic perfor- 
mance. Journal of Applied Corporate Finance, 4(4), 12-22. https:// doi.org/10.1111/j.1745-6622.1992. tb00214.x

18. Merton, R. C. (1995). A Functional Perspective of Financial Intermediation. Financial Management, 24(2), 23-41. Retrieved from https://www.jstor.org/ stable/3665532

19. Michalopoulos, S., Laeven, L., \& Levine, R. (2009). Financial Innovation and Endogenous Growth (NBER Working Paper No. 15356). Retrieved from http://www.nber. org/papers/w15356

20. Mtar, K., \& Belazreg, W. (2021). Causal Nexus Between Innovation, Financial Development, and Economic Growth: the Case of OECD Countries. Journal of the Knowledge Economy, 12, 310-341. https://doi.org/10.1007/s13132020-00628-2

21. Nazir, M. R., Tan, Y., \& Nazir, M. I. (2021). Financial innovation and economic growth: Empirical evidence from China, India and Pakistan. International Journal of Finance \& Economics, 26(4), 60366059. https://doi.org/10.1002/ ijfe. 2107

22. OECD. (2021). ANBERD (Analytical Business Enterprise Research and Development) database. Retrieved from http://oe.cd/anberd

23. Olaniyi, C. O., \& Oladeji, S. I. (2020). Interplay between financial sector and institutional framework in the economic growth process of Kenya. Journal of Public Affairs. https://doi.org/10.1002/pa.2562

24. Pradhan, R. P., Arvin, M. B., \& Bahmani, S. (2018). Are innovation and financial development causative factors in economic growth? Evidence from a panel granger causality test. Technological Forecasting and Social Change, 132, 130-142. https://doi. org/10.1016/j.techfore.2018.01.024

25. Qamruzzaman, M., \& Jianguo, W. (2017). Financial innovation and economic growth in Bangladesh. Financial Innovation, 3(1), 1-24. https://doi.org/10.1186/s40854017-0070-0

26. Rzayev, A., \& Samoilikova, A. (2020). Innovation Financing Structure as a Factor of Economic Growth: Cross Country Analysis. Marketing and Management of Innovations, 3, 133-156. https://doi. org/10.21272/mmi.2020.3-10

27. Sahay, R., Čihák, M., N’Diaye, A. P., Barajas, R. B., Ayala, D., Gao, Y., Kyobe, A., Nguyen, L., Saborowski, C., Svirydzenka, K., \& Yousefi, S. R. (2015). Rethinking Financial Deepening: Stability and Growth in Emerging Markets (IMF Staff Discussion Note No. SDN/15/08). International Monetary Fund. Retrieved from https://www.imf. org/external/pubs/ft/sdn/2015/ sdn1508.pdf

28. Schumpeter, J. A. (2017). The Theory of Economic Development: An Inquiry into Profits, Capital, Credit, Interest, and the Business Cycle ( $1^{\text {st }}$ ed.). New York: Routledge. https:// doi.org/10.4324/9781315135564

29. Shapoval, Y., Shkliar, A., ShpanelYukhta, O., \& Gruber, K. (2021). The level of financial inclusion in Ukraine: Measuring access, quality, and usage of financial products and services. Banks and Bank Systems, 16(2), 59-67. https://doi. org/10.21511/bbs.16(2).2021.06

30. The World Bank. (n.d.). World Bank Open Data. Retrieved from https://data.worldbank.org/

31. Trinugroho, I., Law, S. H., Lee, W. C., Wiwoho, J., \& Sergi, B. S. (2021). Effect of financial development on innovation: Roles of market institutions. Economic Modelling, 103, 105598. https://doi.org/10.1016/j.econmod.2021.105598

32. Tufano, P. (2003). Financial innovation. In G. M. Constantinides, M. Harris, \& R. M. Stulz (Eds.), The Handbook of the Economics of Finance (pp. 307-335). Elsevier. https://doi.org/10.1016/S15740102(03)01010-0

33. Williams, K. (2019). Do political institutions improve the diminishing effect of financial deepening on growth? Evidence from developing countries. Journal of Economics and Business, 103, 13-24. https://doi.org/10.1016/j. jeconbus.2018.11.003

34. Worldwide Governance Indicators. (n.d.). Home. Retrieved from https://info.worldbank.org/governance/wgi 